\section{A birthday celebration}

\section{ASHLEY HEENAN}

To mark Douglas Lilburn's 75th birthday a special concert of his works was given in the National Library auditorium on Thursday, 1 November 1990 at which the Lilburn Catalogue was launched by Ashley Heenan. This is a shortened version of the address he gave on that occasion.

In 1956 Douglas Lilburn and I were summoned to Sydney by the Australasian Performing Right Association (APRA) where, we understood, discussions were to take place with 'serious executives' and 'members of the organization' all aimed at establishing within New Zealand an independent APRA committee to act as a sort of general factotum in music, largely to seek out and select New Zealand music for performance.

Suitably impressed by such long-worded sentences and not realising in our kiwi innocence that we were but pawns in a musico-political game, we were retired to the roof of the APRA building in the sun, to examine and report on two huge piles of manuscripts. We viewed with suspicion each other's pile and when it was ultimately discovered not one manuscript was a New Zealand work, somewhere in our 'greenness' we realized it would be a long road before New Zealand composers were recognised for what they are by our Australian friends. We often joked about those music piles, but as the years progressed and New Zealand music did commence to pile up, the master became quite pre-occupied with ideas for an archive of New Zealand music. He recognised that at this early stage of our historical development it was possible to create an archive which would be unique in its completeness. All dreams and ideas require an opportunity for practical realization. The right man in the right place at the right time to provide this was Jim Traue. New Zealand composers should be for ever indebted to his vision in providing that. They might also breathe a sigh of relief that Jill Palmer was also in the right place at the right time.

It is appropriate that during the current Musical Images exhibition, Douglas enjoys a youthful 75 th birthday. We have heard his music rather than discuss it, I prefer to give a few words about the man. A vast array of peoples from many walks of life would wish him well on this occasion. Not only the poets, writers, painters, dramatists, actors and musicians with whom he has shared experience but also the composers who are indebted to his representation and advocacy on their behalf. Through teaching, solicitude, benevolence towards and patronage on behalf of fellow composers, he has effectively smoothed the way for, and encouraged his musical colleagues. The scope of his contact with people is far wider than his retiring nature might have us believe.

It is not what he has derived from our musical spectrum that emerges but rather what he has throughout the years contributed to enhancing it. The concert tonight is tribute from his musical friends. (I'd love to send him one of those SINGING BIRTHDAY MESSENGERS, the reception of which could be interesting.) But the Turnbull has solved the problem. On the eve of his birthday, they have published an inventory of his holdings in the Archive. It is appropriate that this should be the first publication of its kind in which Jill Palmer has carried out her task with distinction.

I have the greatest pleasure, not only in launching this publication but also on behalf of all New Zealand composers and musicians, the Composers Foundation, the Australasian Performing Right Association, the staff of the Archive, Turnbull and National Libraries and the audience here this evening.in wishing the warmest of birthday greetings to the master on his 75th birthday - not to forget the returns.

\section{The Collection of Douglas Lilburn Manu- scripts in the Alexander Turnbull Library. Alezander Turnbull Library/Composers Foun- dation}

The first publication of its kind, this celebratory catalogue, marks the composer's 75 th birthday and a stage in the growth of one of the most important collections of musical material in New Zealand. I used the word 'stage' because it is by no means all housed in Turnbull: a great deal is still with the composer. Yet what is charted here gives a good overall impression of its nature and scope. The earliest items are copies of family documents. Papers relating to his own life and career start around 1932 with the score of his Sonata for piano, op. 1, written instead of an essay on an imperial theme when he was at Waitaki Boys High School.

The nucleus of the collection lies in the music itself - scores, sketches, parts and master tapes of electro-acoustic music. This is almost complete. The outward correspondence includes an intriguing plan for a Glover/Lilburn work as a tribute to Alex Lindsay. There are photographs, ephemera and writings of Lilburn, token of a literary gift as strong as his musical one. The collection is of immense significance, not only to musicians, but to all those involved in New Zealand culture. -JMT Available from the National Library bookshop, P.O. Box 1467, Wellington. $\$ 20$ plus $\$ 3$ p.p. 